\title{
Corruption claims hang over Amazon surveillance system
}

93 per cent enrichment, since the signing in 1978 of the international agreement on Reduced Enrichment for Research and Test Reactors (RERTR), aimed at eliminating civilian trade in HEU. Following its signing, nearly all research reactors in Europe have either converted, or agreed to convert, to the use of LEU.

The Munich university, however, is resisting pressure for a redesign - costly in terms of both time and money - and wants to start building the reactor this year. The government has so far backed its stance. But handwritten notes on the leaked memorandum, written by officials of the research ministry, say that Axmann's position "qualifies the BMBF's arguments considerably". Bernd Neumann, the deputy research minister, told parliament last week that the $\mathrm{BMBF}$, which will co-finance the reactor, might reconsider its previous support for the use of HEU in the light of this new information.

The BMBF has no direct influence over the university, as German universities come under individual Länder rather than the federal government. But as it has foreign policy implications, the federal government could override Bavaria on this matter.

At last week's meeting, US officials rejected a proposal from the university to convert the reactor to LEU after ten years of operation, if this would have no impact on the reactor's performance. The university believes that it could obtain up to ten years' worth of HEU from stocks currently under the control of Euratom.

US officials said that the reactor must be redesigned immediately - with a larger require an increase in power, is to be technically possible. They confirmed that the United States, currently the West's only supplier of HEU, will not supply such fuel for the FRM2 in future. The Euratom Supply Agency, however, is said to be negotiating with Russia for the supply of fuel (see Nature 379, 201; 1996). This has sparked concern among some US congressmen that Euratom appears to be departing from the terms of the nuclear non-proliferation treaty which came into effect in 1970.

Representative Charles Schumer from New York, a Democrat with a special interest in non-proliferation issues, has now written to Warren Christopher, the US Secretary of State, requesting that a \$12-billion agreement under which the United States will buy Russian HEU extracted from nuclear weapons and blend it down to LEU, should be used to stop Russia from selling HEU to Euratom.

Schumer says he will also try to delay congressional approval of the renewal of the US-Euratom agreement - which covers trade in nuclear materials between the United States and Europe, and which expired last month - without a clear indication that Russia will not sell HEU to Euratom.

Alison Abbott \& Quirin Schiermeier reactor core - if conversion, which would
São Paulo. An ambitious US\$1.4-billion radar surveillance system for the Amazon is expected to be approved by the Brazilian government this week, despite opposition from scientists and fallout from a corruption scandal involving government officials and Raytheon, the US company that was awarded the project contract.

Opposition politicians have questioned both the high costs and the legality of the Sistema de Vigilância da Amazônia (Amazon Surveillance System, SIVAM) in the light of the resignation last November of Maura Gandra, the air force minister, over a bribery scandal. Gandra, it has emerged, was friendly with a Raytheon lobbyist alleged to have tried to bribe an opposition senator into supporting SIVAM.

But the government, despite the mounting opposition, is expected to press ahead with its plans to approve SIVAM. President Fernando Henrique Cardoso reaffirmed his support for the project last charged with investigating the corruption allegations is bringing forward the announcement of a decision on the project from 7 February to this week.

SIVAM is designed to improve air traffic control and environmental monitoring in the Amazon basin. Managed by the air force, it combines data from remote-sensing satellites and airborne air control radar. But the project has been dogged by controversy since May 1995, when Raytheon's Brazilian partner, Automation and Control Systems Engineering (ESCA), was disqualified from taking part amid allegations of tax evasion.

The recent bribery allegation emerged when the Brazilian press published transcripts of telephone conversations between Júlio César Gomes dos Santos, the presidential head of protocol, and Jose Affonso Assumpcao, a lobbyist and adviser for Raytheon. Santos is alleged to have asked if Assumpcao had "already paid the guy", referring to a senator opposed to the project. Gandra, who was not air force minister at the time, and Santos have both resigned.

Assumpcao has said he cannot recall any such conversation, but assumed that any question about payments must have been "a joke". Gilberto Miranda, an opposition senator from Amazonas state, has denied any wrongdoing, and claims he would immediately report any attempt to buy his influence.

But SIVAM faces further controversy. The government says the scheme will help to monitor illegal activity such as drugs trafficking and river pollution. Scientists and month, and the senate committee

opposition politicians, however, believe that the project is expensive, unnecessarily complicated and irrelevant, and favour a cheaper alternative incorporating local know-how.

The Brazilian Society for the Progress of Science (SBPC), for example, says Brazil's problems of deforestation, land use and pollution derive from inadequate social, health and education policies and not from a need for a billion-dollar surveillance system.

Scientists also question SIVAM's net value to Brazilian research. They argue that the project largely ignores indigenous capacity in universities, research institutes and industry and complain that even the Nation-

IMAGE
UNAVAILABLE
FOR COPYRIGHT
REASONS

al Institute for Space Research (INPE) has only a minor share in the project, despite providing most of the personnel for SIVAM's remote sensing operation.

"It is a lost opportunity," says Rogério Cézar de Cerqueira Leite, a physicist at Campinas University. Earlier this month, Leite wrote a newspaper article in which he suggested that SIVAM included "obsolete paraphernalia" and was inefficient. "Brazil could produce a more efficient and cheaper system itself," he wrote.

Last week, the committee of the Brazilian Senate set up to investigate the corruption allegations prevented a SIVAM critic, a former director of research and development at the Brazilian air force, from giving evidence. Ivan Frota, a reserve air force general who in 1990 investigated an alternative Amazon surveillance system, which, he says was 42 per cent cheaper than Raytheon's winning bid, was prevented from speaking. He had earlier alleged that the government had been "buying congressmen with favours".

Frota's view that the government has paid too much for SIVAM has since received backing from an opposition politician. Arlindo Chiniaglia, of the Workers' Party in São Paolo, has alleged that Raytheon could be overcharging for the project by as much as 55 per cent. The SBPC, which has assessed Chiniaglia's claims, believes the figure amounts to about 40 per cent.

Ricardo Bonalume Neto 